ANNA WINIARCZYK-RAŹNIAK

Uniwersytet Pedagogiczny w Krakowie

PIOTR RAŹNIAK

Krakowska Akademia im. Andrzeja Frycza-Modrzewskiego

\title{
Poziom zadowolenia turystów zagranicznych a perspektywy wzrostu ruchu turystycznego w Meksyku
}

\section{WPROWADZENIE}

Meksyk to kraj o różnorodnej kulturze i urozmaiconych krajobrazach, zachwyca przyjezdnych rozmaitymi zabytkami, dźwiękami, smakami i zapachami. Przyciąga turystów pięknymi piaszczystymi plażami Jukatanu, nowymi i starymi kurortami, dającymi możliwość atrakcyjnego spędzenia wolnego czasu. Jednak Meksyk to nie tylko plaże i ciepłe morze. W głębi wilgotnego lasu deszczowego ukrytych jest wiele zabytków z czasów prekolumbijskich, coraz częściej odwiedzanych przez zagranicznych turystów. Dodatkowym atutem jest także wspaniała kultura, na którą składają się zarówno wpływy europejskie, jak i kultur historycznych, m.in. Majów, Azteków i Olmeków. Różnorodność atrakcji oferowanych w Meksyku skutkowała wzrostem liczby turystów zagranicznych oraz dochodami, jakie generowali. W niniejszym opracowaniu podjęto próbę wykazania zależności zachodzących pomiędzy satysfakcją z pobytu w Meksyku a wzrostem liczby turystów oraz dochodów płynących z turystyki. Ukazano również prognozę rozwoju sektora turystycznego na II dekadę XXI w.

\section{PoZIOM SATYSFAKCJI TURYSTÓW ZAGRANICZNYCH Z POBYTU w MEKSYKU}

Badania satysfakcji turystów prowadzone są od 2001 r. przez Secretaria del Turismo wśród osób przybywających drogą powietrzną do Meksyku (Perfil del Turista Intenacional Aereo 2002). W 2007 r. badaniem objęto 13 lotnisk i przeprowadzono 2435 wywiadów ankietowych wśród zagranicznych respondentów pod kątem zadowolenia ze stanu infrastruktury turystycznej, lotniskowej oraz nastawienia mieszkańców do turystów zagranicznych. Pytano o zadowolenie z transportu publicznego, czystości w docelowym miejscu przyjazdu i w porcie lotniczym, szybkości odprawy paszportowej, dostępności informacji turystycznej, perspektyw interesującego spędzenia czasu, restauracji, możliwości zakupów (w tym rów- 
nież pamiątek), gościnności mieszkańców oraz bezpieczeństwa. Respondenci mogli podać cztery odpowiedzi oceniające wymienione powyżej aspekty: „znakomicie”, „dobrze” „słabo” oraz „bardzo słabo”. Po zagregowaniu otrzymanych wyników wyznaczono cztery klasy ocenianych cech:

0-6,99 - brak zadowolenia,

$7-7,99$ - raczej zadowoleni

8-8,99 - zadowoleni

9-10 - bardzo zadowoleni

Wyniki zestawiono z podobnym badaniem, które przeprowadzono w 2002 r. (ryc. 1).

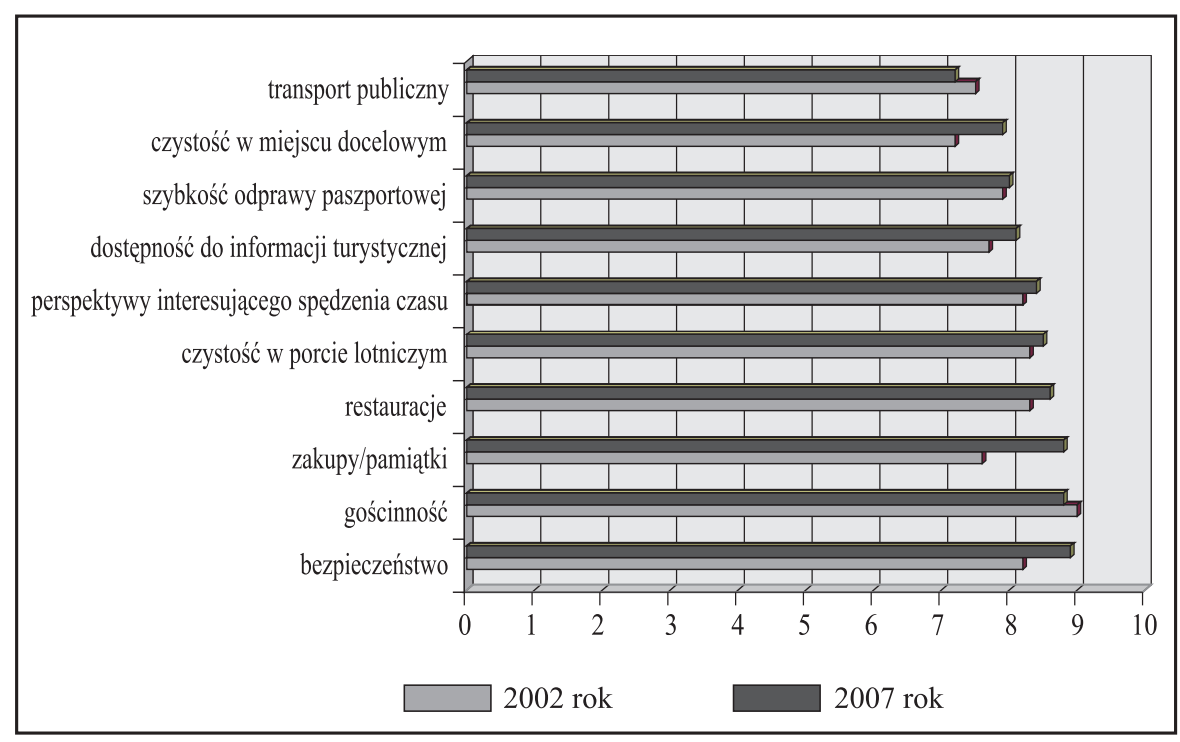

Ryc. 1. Poziom zadowolenia turystów zagranicznych przybywających do Meksyku samolotem w 2002 i $2007 \mathrm{r}$.

Źródło: opracowanie własne na podstawie Perfil del Turista internacional aereo, 2002, Perfil y Grado de Satisfaccion de los Turistas 2007

Turyści zagraniczni przybywający do Meksyku drogą powietrzną w 2002 r. najwyżej ocenili czystość panującą na lotniskach oraz usługi gastronomiczne, których średnia ocena wyniosła 8,0 pkt. Zadowoleni byli również poziomem bezpieczeństwa oraz ofertami spędzenia czasu, jakie daje Meksyk. Najniższy poziom z satysfakcji zanotowano w przypadku czystości (7,2 pkt.) oraz stanu transportu publicznego (7,5 pkt.). Średnia dla 10 badanych wskaźników w omawianym roku wyniosła 8,0 pkt., co wskazuje, iż napływający byli zadowoleni z pobytu w omawianym kraju. W 2007 r. aż na 8 z 10 pytań respondenci dali wyższe noty niż 5 lat wcześniej. Najwięcej powodów do zadowolenia przysporzyło bezpieczeństwo (8,9 pkt.), gościnność mieszkańców ( 8,8 pkt.) oraz przyjemność wynikająca z zakupów oraz różnorodności oferowanych pamiątek (8,8 pkt.). Nadal dopracowania wymaga stan transportu publicznego oraz czystości, która jednak zanotowała najwyższy wzrost ocen z 7,2 pkt. w 2002 r. do 7,9 pkt. w 2007 r. Oprócz czystości największą poprawę zauważono w przypadku bezpieczeństwa ( $+0,7$ pkt.) oraz dostępności do informacji turystycz- 
nych (+0,4 pkt.). Jedynie dwa wskaźniki legitymowały się gorszymi wynikami w 2007 roku i była to gościnność mieszkańców oraz stan transportu publicznego, jednak spadki były nieznaczne i wyniosły odpowiednio 0,3 oraz 0,2 pkt. Generalnie poziom satysfakcji turystów przybywających z zagranicy wzrósł o 0,3 do 8,3 pkt., co może sugerować, iż Meksyk staje się coraz bardziej atrakcyjnym i coraz lepiej przygotowanym miejscem do wypoczynku (Perfil y Grado de Satisfaccion de los Turistas, 2007).

Respondenci w 2007 r. oceniali również poziom zadowolenia z miejsca wypoczynku (ryc. 2). Spośród 13 ośrodków docelowych jedynie 3 leżą w głębi kraju i są to miasta: Oaxaca, Queretaro oraz Guadalajara. Najwyższym poziomem zadowolenia charakteryzowały się kurorty położone w stanie Quintana Roo na półwyspie Jukatan. Cancun, Riviera Maya, Cozumel oraz Isla Mujeres należą do najnowszej, trzeciej generacji kurortów nadmorskich Meksyku zbudowanych na wybrzeżu Morza Karaibskiego, charakteryzujących się również wysokim poziomem komfortu i usług turystycznych (Smith 2009). Może to być przyczyną ich popularności wśród osób szukających przede wszystkim „słońca i plaży" (Escudero 2008). Omawiany teren objęty jest również międzynarodowym programem Mundo Maya, który ma na celu restaurację zabytków starożytnych Majów oraz ich propagowanie wśród turystów (Podleśna 2005). Na wschodnim wybrzeżu Jukatanu, gdzie w pobliżu pięknych plaż powstały nowe luksusowe hotele, tworzone są również obiekty o niższym standardzie przeznaczone dla mniej zamożnych podróżnych. Wysoki poziom zadowolenia zaznaczył się również w luksusowym przedwojennym kurorcie, nastawionym na zamożnych turystów Puerto Vallarta, położonym w środkowej części wybrzeża Oceanu Spokojnego. Nieco niżej ocenione zostały miasta położone w głębi kraju, z których najwyższymi notami legitymuje się stolica stanu Chiapas-Oaxaca - położona w malowniczej dolinie. Najniższym wskaźnikiem charakteryzowało się nieco zaniedbane Puerto Escondido położone kilkanaście kilometrów od wybrzeża Oceanu Spokojnego.

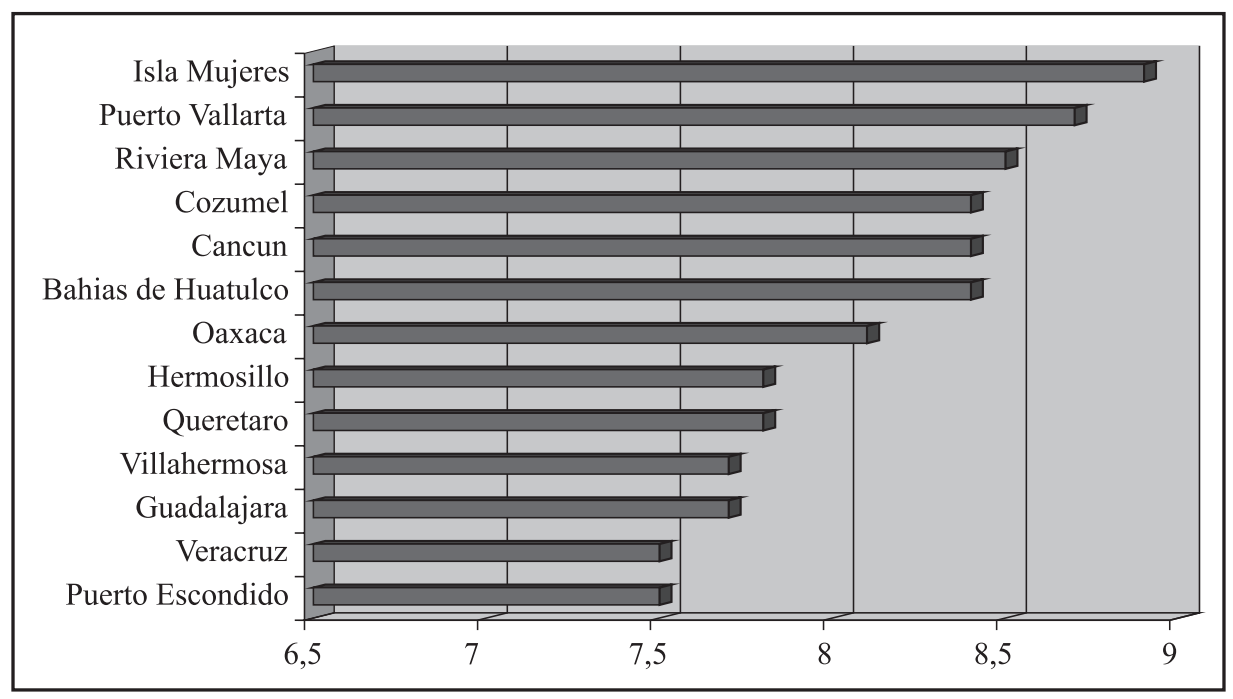

Ryc. 2. Poziom zadowolenia turystów zagranicznych przybywających samolotem według miejsca docelowego pobytu w $2007 \mathrm{r}$.

Źródło: opracowanie własne na podstawie Perfil y Grado de Satisfaccion de los Turistas 2007 


\section{KIERUNKI PRZYJAZDÓW TURYSTÓW ZAGRANICZNYCH}

ORAZ PERSPEKTYWY DO 2020 ROKU

Od II wojny światowej Meksyk notuje stały wzrost zainteresowania wśród przyjeżdżających z zagranicy: z 0,95 mln w 1950 r., 5,8 mln w 1970 r. do ponad $10 \mathrm{mln}$ na przełomie XX i XXI stulecia (tab. 1). Szybko rozwijający się przemysł turystyczny spowodował również gwałtowne powiększenie się liczby miejsc hotelowych, ich liczba w ciągu 50 lat wzrosła ponadośmiokrotnie. W pierwszej dekadzie XXI w. nastąpił dalszy wzrost liczby przyjeżdżających, przy jednoczesnym zwiększeniu satysfakcji z pobytu. Zadowolenie turystów zagranicznych może spowodować, iż analizowane państwo będzie postrzegane jako kraj idealny do wypoczynku. Może się to w przyszłości przełożyć na dalszy wzrost liczby przyjeżdżających oraz generowanych przez nich dochodów.

Tab. 1. Prognoza ruch turystyki przyjazdowej oraz udział głównych regionów świata

\begin{tabular}{|l|r|r|r|r|r|c|}
\cline { 2 - 7 } \multicolumn{1}{c|}{} & 2000 & $\%$ & 2010 & $\%$ & 2020 & $\%$ \\
\hline Stany Zjednoczone & 9673 & 88,0 & 13817 & 87,1 & 18355 & 86,0 \\
\hline Kanada & 323 & 2,9 & 447 & 2,8 & 635 & 3,0 \\
\hline Europa & 446 & 4,1 & 718 & 4,5 & 1017 & 4,8 \\
\hline Ameryka Łacińska & 498 & 4,5 & 826 & 5,2 & 1264 & 5,9 \\
\hline Pozostałe regiony & 48 & 0,4 & 61 & 0,4 & 74 & 0,3 \\
\hline Razem & 10988 & 100,0 & 15869 & 100,0 & 21345 & 100,0 \\
\hline
\end{tabular}

Źródło: opracowanie własne na podstawie Estudio de Gran Visión del Turismo en México 2000

W 2000 r. do Meksyku przybyło prawie 11 mln turystów zagranicznych. W kolejnych dwóch dekadach prognozuje się stałe zwiększenie tej liczby, która w 2020 r. ma przekroczyć $21 \mathrm{mln}$. Zdecydowanie najwięcej turystów w napłynęło i będzie napływać ze Stanów Zjednoczonych. W 2000 r. było ich niespełna 9,7 mln, w ciagu dwóch dekad ma się podwoić. Również z pozostałych kierunków prognozowany jest stały wzrost liczby przybywających. W omawianym dwudziestoleciu zdecydowanie największy udział mieli obywatele Stanów Zjednoczonych, którzy w 2000 r. stanowili aż 88\% przyjezdnych. Przewiduje się jednak nieznaczny spadek liczby przyjeżdżających z tego kierunku - o 2 punkty procentowe - na rzecz dynamicznie zwiększających się przyjazdów z Ameryki Łacińskiej, której udział zwiększy się z 4,5\% w 2000 r. do 5,9\% w 2020 r. Duże nadzieje wiązane są z przyrostem liczby odwiedzających z krajów europejskich, których udział również powinien się zwiększyć. Z kolei przyjazdy z Kanady prawdopodobnie pozostaną na podobnym poziomie, natomiast pozostałe kierunki legitymują się udziałem poniżej $0,4 \% \mathrm{w}$ trzech analizowanych latach.

Przyjazdy zza północnej granicy można podzielić na dwie grupy: rdzennych Amerykanów oraz Meksykanów mieszkających w Stanach Zjednoczonych (ryc. 3). Dominują obywatele USA, jednak udział emigrantów odwiedzających ojczyznę systematycznie wzrastał z ok. 28\% w 1995 r. do 35\% 2005 r. Przewidywane jest dalsze zwiększanie się udziału przyjazdów ludności pochodzenia meksykańskiego do około 38\% w 2020 r. Kilkumilionowe przyjazdy do ojczyzny mogą wiązać się z odwiedzinami rodziny. Pewnym ułatwieniem i obniżeniem 
kosztów podróży może być koncentracja ludności meksykańskiej w południowych i zachodnich stanach USA (Zuniga, Hernandez-Leon 2006). Historyczny i perspektywiczny wzrost odwiedzin własnego kraju może mieć związek z poprawą sytuacji materialnej i większymi możliwościami finansowymi emigrantów meksykańskich (Estudio de Gran Visión del Turismo en México 2000).

Regionem, z którego najbardziej dynamicznie ma wzrastać liczba przyjeżdżających, jest Ameryka Łacińska. W II połowie lat 90. (ryc. 4). zanotowano nieznaczny wzrost napływających z ok. 430 tys. w 1995 r. do 500 tys. w roku 2000. W kolejnej dekadzie notowano dynamiczny wzrost, który w drugiej połowie II dekady XXI w. ma przekroczyć $1 \mathrm{mln}$ turystów. Lata 90. charakteryzowały się znaczną zmiennością dynamiki napływu. W 1996 r. zanotowano spadek o 1,5\%, podczas gdy rok później odnotowano wzrost o ponad 8\% w stosunku do poprzedniego. Pierwsza dekada XXI w. cechowała się szybkim wzrostem, natomiast po 2010 r. prognozuje się dynamikę przyjazdów na poziomie 4-4,5\%. Analizowany aspekt stawia Amerykę Łacińską na pierwszym miejscu pod względem prognozowanego wzrostu zagranicznej turystyki przyjazdowej do Meksyku.

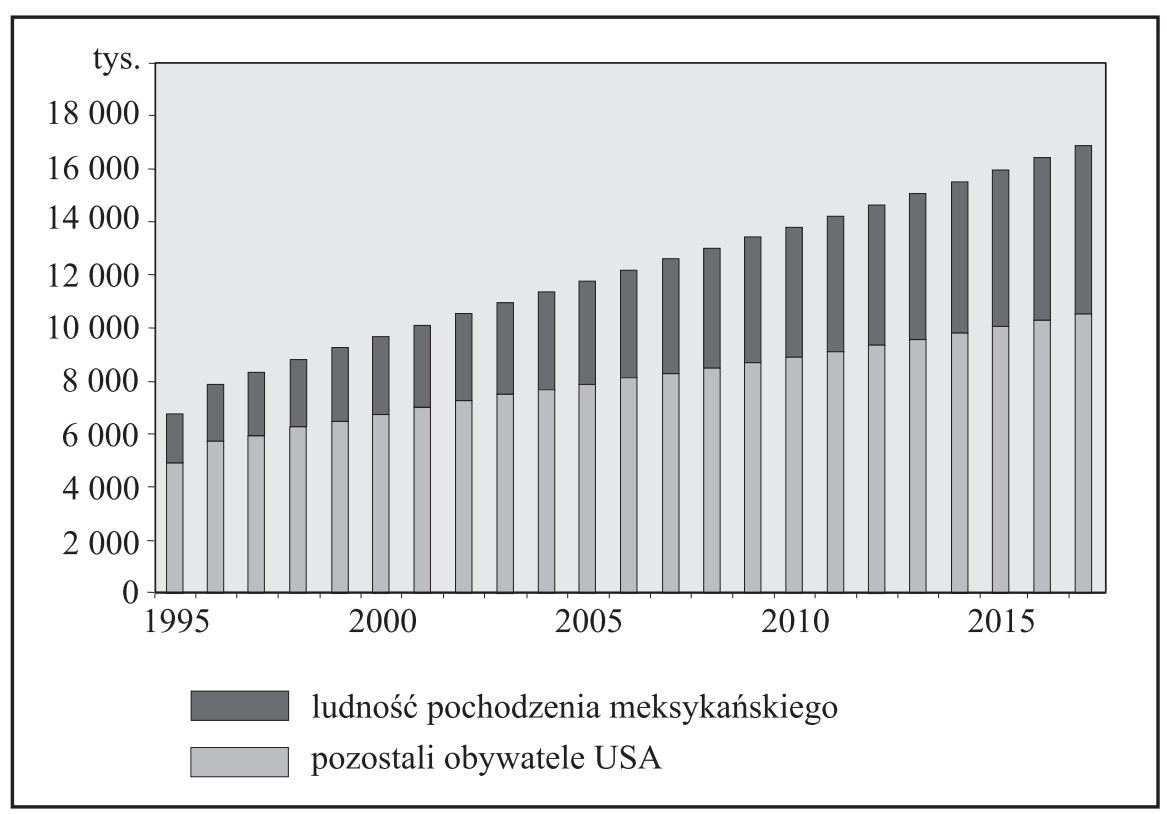

Ryc. 3. Turyści przyjeżdżający do Meksyku ze Stanów Zjednoczonych 


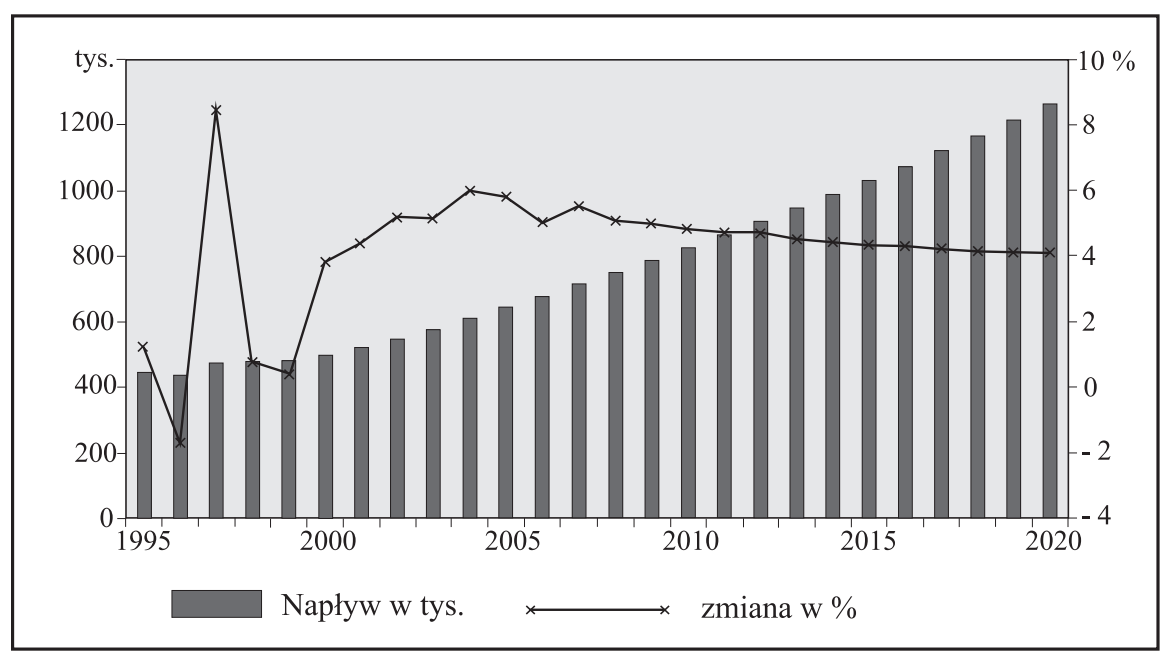

Ryc. 4. Turyści przyjeżdżający do Meksyku z Ameryki Łacińskiej

Źródło: Estudio de Gran Visión del Turismo en México 2000

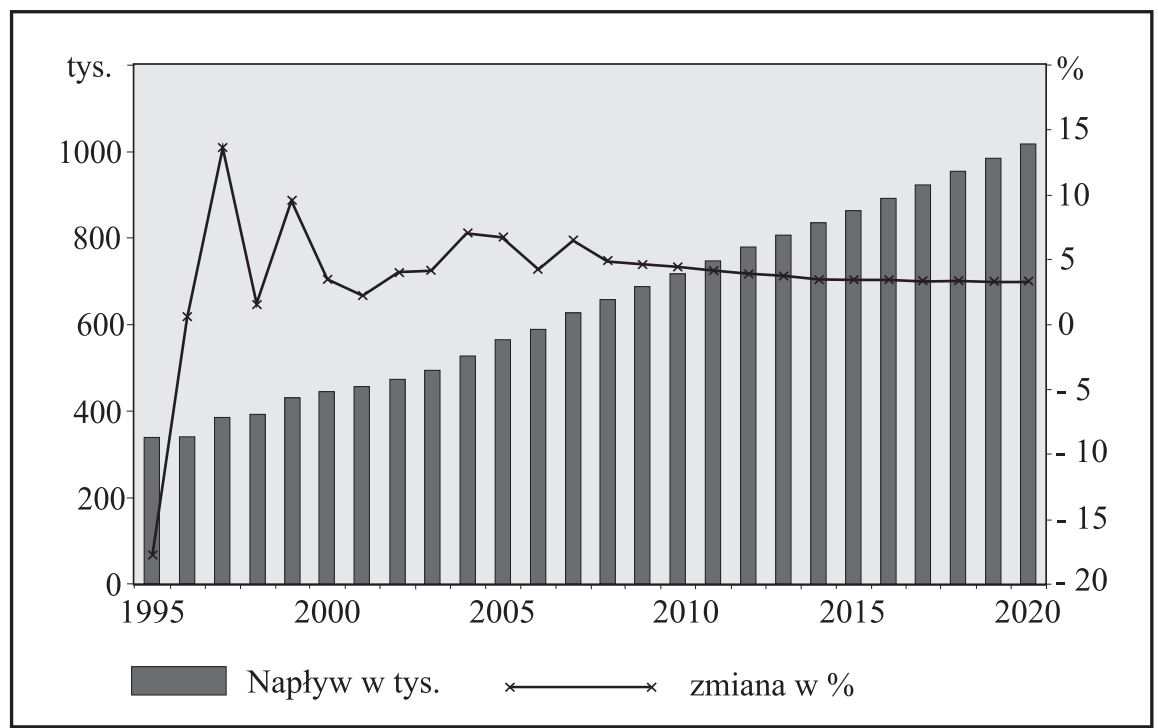

Ryc. 5. Turyści przyjeżdżający do Meksyku z Europy

Źródło: Estudio de Gran Visión del Turismo en México 2000

Kontynentem, który według analiz ma również zwiększać swój udział w ogóle ruchu turystycznego wśród przyjeżdżających, jest Europa (ryc. 5). Od 1995 r. nieustannie rosła liczba przyjeżdżających z $0,3 \mathrm{mln}$ do ponad $0,5 \mathrm{mln}$ w 2005 r. Również w przyszłości Meksyk ma być się coraz bardziej atrakcyjnym miejscem wypoczynku Europejczyków, co ma się przełożyć na ponadmilionową rzeszę odwiedzających pod koniec II dekady XXI w. Po jed- 
norocznym spadku zainteresowania analizowanym krajem w 1996 r. w stosunku do 1995 r. nastąpił dynamiczny wzrost przyjeżdżających o $15 \% \mathrm{w}$ porównaniu do roku poprzedniego. Natomiast na początku pierwszej dekady r. 2000 omawiany współczynnik ustabilizował się na poziomie ok. 5\%, a w przyszłości ma jeszcze nieznacznie się obniżyć. Jednak prognozuje się stały przyrost odwiedzających na poziomie 3-4\% rocznie do $2020 \mathrm{r}$.

Wraz z rozwojem popularności Meksyku wśród mieszkańców Europy powiększać się będą również wydatki turystów (ryc. 6). Warto zauważyć, iż mimo spadku liczby przybywających w r. 1996 o ok. 15\%, wzrosła suma wydana przez nieco mniejszą liczbę wypoczywających o $20 \%$. W późniejszym okresie obserwować można stały wzrost dochodów generowanych przez Europejczyków, który ma się utrzymać do końca analizowanego okresu. Warto zauważyć, iż dochody generowane przez turystów z omawianego kontynentu rosły i będą rosnąć szybciej niż liczba przybywających, co niewątpliwie jest bardzo pozytywnym zjawiskiem. W II dekadzie XXI w. prognozuje się średni wzrost wydatków na turystę europejskiego na poziomie ok. 2,2-2,5\% rocznie. W 2010 r. wydatki mają wynieść ok. $800 \mathrm{mln}$ USD w porównaniu do $1200 \mathrm{mln}$ USD w $2020 \mathrm{r}$.

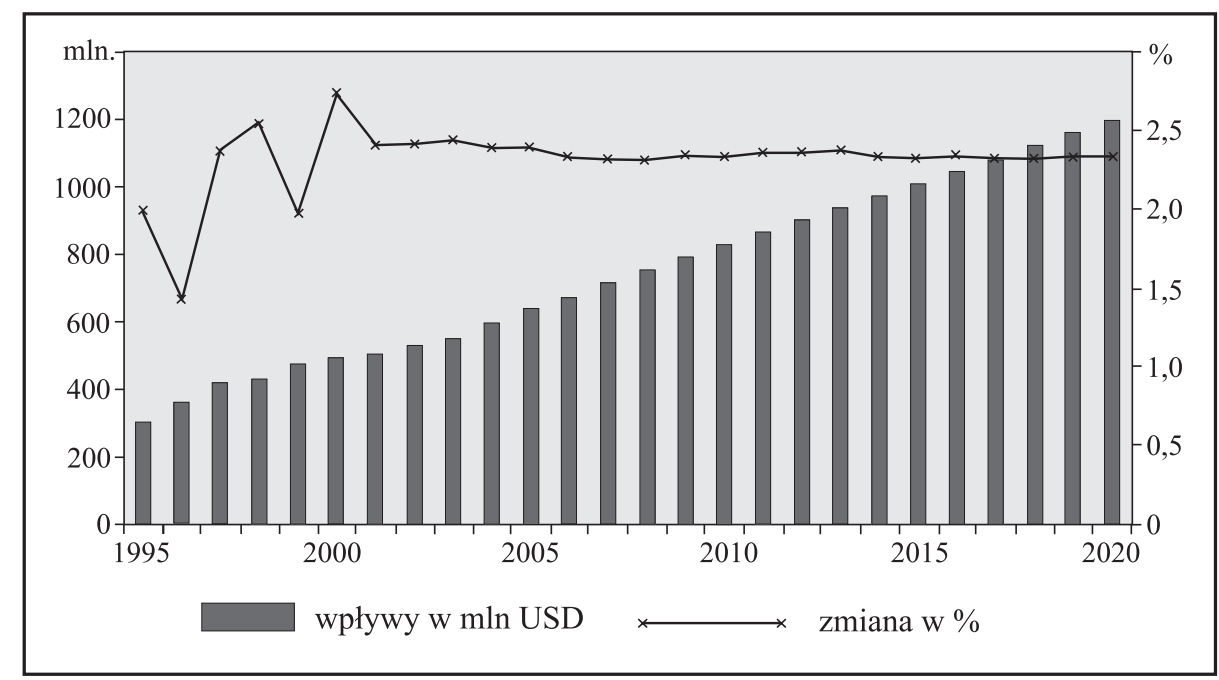

Ryc. 6. Turyści przyjeżdżający do Meksyku z krajów europejskich

Źródło: Estudio de Gran Visión del Turismo en México 2000

\section{PODSUMOWANIE}

Wysoki poziom satysfakcji z usług turystycznych może się przełożyć na wzrost zainteresowania danym krajem jako miejscem spędzania wolnego czasu. Dobra opinia wyjeżdżających przekazana innym osobom także może mieć wpływ na przyszłe decyzje kolejnych potencjalnych przyjezdnych. Badane współczynniki, dotyczące satysfakcji turystów, zarówno w 2002 r. jak i 2007 r. wykazały, iż większość osób przyjeżdżających z zagranicy było zadowolonych z pobytu. Wzrost wartości wskaźników w 2007 r. wskazuje, iż jakość obsługi i infrastruktury poprawia się, co w przyszłości może zaowocować zwiększonymi przyjazdami. W analizowanym okresie stwierdzono zarówno wzrost liczby odwiedzających, jak 
i dochodów generowanych przez sektor turystyczny. Badanie satysfakcji przyjeżdżających z zagranicy pozwala na stwierdzenie, iż wzrost zadowolenia może mieć wpływ na zwiększone przyjazdy turystów zagranicznych i dochody z analizowanej branży. Jeżeli ta tendencja się utrzyma, to można spodziewać się, iż wartości prognozowane na II dekadę XXI w. zostaną osiagnięte.

\section{Literatura}

Estudio de Gran Visión del Turismo en México: Reporte Analítico, Perspectiva 2020, 2000, Secretaria de Turismo, Mexico, p. 174.

Perfil del Turista Intenacional Aereo, 2002, Centro de Estudios Superiores en Turismo, Secretaria del Turismo, Mexico, p. 6.

Perfil y Grado de Satisfaccion de los Turistas, 2007, Reporte con los resultados segmentos, Centro de Estudios Superiores en Turismo, Secretaria del Turismo, p. 30.

Pick J., Hettrick J., Butler E., Funakoshi K., 2001, Tourism in Mexico, it's development, dependency and spatial patterns, The Business Association of Latin American Studies, San Diego, USA, p. 295-305.

Escudero N., 2008, Turismo internacional de playa y cambio climatico en Mexico, Revista de la facultad de derecho en Mexico, t. LVIII, num. 250, p. 641-672.

Podleśna M., 2005, Program Mundo Maya, [w:] Afryka, Ameryka, Azja, t. 82, Wydział Studiów Regionalnych UW, Warszawa 2005, s. 103-122.

Smith J., 2009, Three generations of international tourist resorts in Mexico, Geographische Rundschau International Edition, Vol. 5, No 1, p. 4-10.

Zuniga V., Hernandez-Leon R., 2006, New destinations Mexican immigration in the United States, Russel Sage Fundation, New York 2006, p. 256.

\section{Foreign tourist satisfaction levels and potential for growth in tourist traffic to Mexico}

The paper is dedicated to the issue of the relationship between the level of satisfaction of foreign tourists visiting Mexico and the potential for growth in the number of persons visiting from abroad. The publication is based on survey research conducted by the Mexican agency "Secretaria del Turismo" among tourists arriving by air. The survey asked participants to rate the state of the Mexican tourist infrastructure, airport facilities, and attitudes of locals towards foreign tourists. The survey study showed a general increase in the satisfaction level of people who had visited Mexico in 2007 relative to that of people who had visited in 2002. Security and Mexican hospitality were highly rated by survey participants. Forecasts call for growth in tourist traffic and predict increasing revenues for the tourist industry. This may be associated with the growing level of satisfaction experienced by visitors to Mexico.

dr Anna Winiarczyk-Raźniak

Uniwersytet Pedagogiczny im. Komisji Edukacji Narodowej w Krakowie

arazniak@poczta.fm

dr Piotr Raźniak

Krakowska Akademia im. Andrzeja Frycza-Modrzewskiego

razny1@tlen.pl, 